\title{
Composition and properties of Finnish honey and their dependence on the season, region, bee race and botanical origin
}

\author{
ANNA-LIISA VARIS, JUHA HELENIUS AND KARI KOIVULEHTO \\ Department of Agricultural and Forest Zoology, University of Helsinki, \\ SF-00710 Helsinki 71
}

\begin{abstract}
Analyses were made of regionally representative samples of Finnish honey, 90 from 1977 and 68 from 1978. The average sugar composition, determined by thin layer chromatography, was: $47.3 \%$ fructose, $43.9 \%$ glucose and $8.7 \%$ oligosaccharides. The ratio fructose/glucose was 1.1 . Dry matter averaged $82.4 \%$ and $\mathrm{pH}$ 3.9. Vitamin analysis of five subsamples gave $2700 \mu \mathrm{g} / 100 \mathrm{~g}$ ascorbic acid, $9 \mu \mathrm{g} /$ $100 \mathrm{~g}$ thiamine, $39 \mu \mathrm{g} / 100 \mathrm{~g}$ riboflavin and $1020 \mu \mathrm{g} / 100 \mathrm{~g}$ niacin. The proportion of glucose was positively and the proportion of oligosaccharides negatively correlated to the count of Brassicaceae pollen in honey. The tendency to crystallize was explained better by the ratio glucose/oligosaccarides than by the ratios fructose/glucose, glucose/water or (glucose-water)/fructose. In sugar composition and in tendency to crystallize, seasonal and regional variation existed.
\end{abstract}

\section{Introduction}

The main components of honey are various sugars. It is a difficult task to analyse the sugars of honey in detail, and suitable methods are still to be developed (e.g. DONER 1977). However, the average composition of the world honeys is $15-26 \%$ water, $22-54 \%$ fructose and $20-54 \%$ glucose, the remaining ca. $12 \%$ consisting of oligosaccharides and other components (e.g. WHITE 1975, DONER 1977).

The 21 samples of Finnish honeys from 1937 and seven samples from 1938 analysed by MARTIMO (1945) averaged $81.1 \%$ dry matter, $70.7 \%$ fructose and glucose, $1.8 \%$ saccharose, $\mathrm{pH} 3.91$ and diastase activity 14.9 . PUROKOSKI and FORSIUS (unpublished) 1 analysed 120 samples of Finnish honey from 1962 and 1963. The average composition and the general appearance was: colour light yellow or yellow, consistency crystallized, DM $83.3 \%$, total sugars $77 \%$, fructose $38.5 \%$, glucose $34.5 \%$, saccharose 1.2

${ }^{1}$ PUROKOSKI, P. \& FORSIUS, A. Suomalaisen hunajan koostumuksesta ja siihen vaikuttavista tekijöistä. Manuscr. 60 p. Material originating from 1962, 1963. State Inst. Agric. Chem., Helsinki. 
$\%$, maltose $1.5 \%$, ratio fructose/glucose $(\mathrm{F} / \mathrm{G}) 1.1, \mathrm{pH} \mathrm{3.8}$, free acid 1.8 $\mathrm{meq} / 100 \mathrm{~g}$, lactone $0.7 \mathrm{meq} / 100 \mathrm{~g}$, total acidity $2.5 \mathrm{meq} / 100 \mathrm{~g}$, formol number 0.51 , nitrogen $0.05 \%$, protein precipitate (by phosphotungstic acid) $0.9 \mathrm{ml}$, hydroxymethylfurfural $0.3 \mathrm{mg} \%$, diastase activity 25 and invertase activity 12.

In general, honey is supersaturated with respect to glucose. As glucose is the crystallizing component, nearly all types of honey crystallize. According to WHITE et al. (1962), the ratio glucose water (G/W) is the best indicator of the crystallization tendency of honey. PUROKOSKI and FORSIUS (see above) found that both the G/W and F/G ratios were connected with crystallization. On the other hand, CHANDLER et al. (1974) did not consider any of the generally used indices, G/W, F/G or $(\mathrm{G}-\mathrm{W}) / \mathrm{F}$, to be useful as indicator of crystallization. HADORN and ZURCHER (1974) found the indices F/G and G/W unsatisfactory for over $40 \%$ of their samples. TABOURET (1979) pointed out the importance of water activity in explaining crystallization.

MAURIZIO (1964) emphasized the connection of the sugar composition with the botanical origin of honey. POURTALLIER and TALIERCIO (1970) even considered the sugar spectrum to be more accurate than the pollen spectrum for determining the botanical origin of honey. RAVN et al. (1975) discovered relationships between the pollen composition determined by quantitative pollen analysis and the oligosaccharide content. For example, rape (or Brassica) honeys have been reported to have a higher than average proportion of glucose (PUROKOSKI and FORSIUS, unpublished, MAURIZIO 1964, POURTALLIER and TALIERCIO 1970) and a lower than average poportion of oligosaccharides (POURTALLIER and TALIERCIO 1970, RAVN et al. 1975). However, serious difficulties still remain in determining the botanical origin of honey, and thus the results concerning the chemical properties of honeys of assumed botanical origin are not exact.

The purpose of this study was to elucidate the general chemical composition of Finnish honey, and to explain the main factors responsible for its variation. Some attention was paid to the connection between chemical properties and pollen compositon.This is the second article on material collected in 1977 and 1978. The first dealt with the pollen spectrum of Finnish honey (VARIS et al. 1982).

\section{Material}

Altogether 158 honey samples, 90 in 1977 and 68 in 1978, were collected from beekeepers. The material was regionally representative of Finland and was the same as described in VARIS et al. (1982), except that two samples obtained in 1977 and 1978 from an apiary in zone I were excluded because they were too small. For details, see VARIS et al. (1982). 


\section{Methods}

The samples were analysed for fructose, glucose and oligosaccharides, $\mathrm{pH}$ and dry matter. Crystallization was rated by eye. Vitamins $C, B_{1}, B_{2}$ and niacin were determined from five subsamples. Six honeys taken at random from 1977 and four from 1978 were analysed for acidity, diastase activity and hydroxymethylfurfural. The groupings for statistical comparisons were done by seasons, by agricultural zones $\mathrm{I}-\mathrm{IV}+\mathrm{V}$, by bee race and by date of removal of the crop from the hive. Correlations with pollen components were calculated; here the data presented by VARIS et al. (1982) were utilized.

\section{Sugar analysis}

Thin layer chromatography has been applied in determining honey sugars, e.g. by SIDDIQUI and FURGALA $(1967,1968)$ and GREENWAY et al. (1975). The method used is an application of thin layer chromatography for semiquantitative analysis of fructose, glucose and oligosaccharides.

Developing solution: Ethyl acetate $10 \mathrm{ml}$, acetone $35 \mathrm{ml}$, deionized water $5 \mathrm{ml}$. $\mathrm{ml}$.

Colour reagent: a-naphthol $0.25 \mathrm{~g}$, ethanol $100 \mathrm{ml}$ and sulphuric acid 10

Standard solution: fructose $1 \%$, glucose $1 \%$ and saccharose $0.1 \%$. The 5 $\%$ sample solutions were prepared with a refractometer. The layers were: TLC aluminium sheets, silicagel 60 (without fluorescent indicator), precoated, $20 \times 20 \mathrm{~cm}^{2}$, layer thickness $0.2 \mathrm{~mm}$, Art. 5553 MERCK.

$2 \mu \mathrm{l}$ of sample solution was spurted onto the layer as a thin $1-\mathrm{cm}$ streak. For the standard, $6 \mu \mathrm{l}$ was used. The spurting was done with a gas chromatography syringe. Four samples and the standard were applied to each layer. The developing solution was allowed to concentrate for $30 \mathrm{~min}$ before developing. During the developing time of $90 \mathrm{~min}$, the chamber was not opened. The layers were dried for one hour in room temperature and then sprayed with colour reagent. Ca. $20 \mathrm{ml}$ of colour reagent was used per layer. After dyeing, the layers were dried in the oven in $+110^{\circ} \mathrm{C}$.

The columns were measured with a densitometer, equipped with a graphic recording device. The diagrams thus obtained presented the amount of each sugar component on the layer. As the diagrams for fructose and glucose partly overlapped, these had to be estimated graphically (Fig. 1). The areas delimited by the curves were measured with a planimeter.

The amout of fructose, for example, was calculated with the following equation, where $\mathrm{A}=$ the area and $\mathrm{X}=$ the amount of fructose. The left side of the equation is a constant:

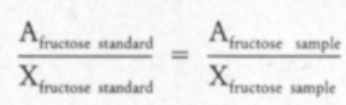

The amounts of glucose and oligosaccharides were calculated analogously. The results were expressed as the percentages of each component in 


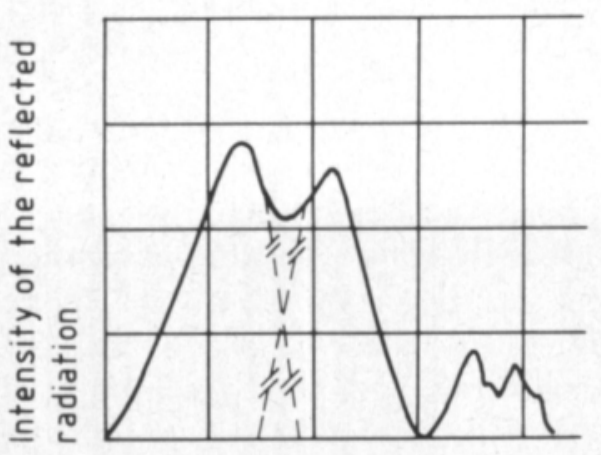

Distance from the base of the column
Fig. 1. Graphic estimation of fructose and glucose from densitometer measurements.

the sum of the three components. A source of error was that the equation presumes a linear relation between the amount of the sugar and the corresponding area, which is not absolutely true. Some inaccuracy was caused by the fact that the oligosaccharide component was calculated using pure saccharose as standard. The oligosaccharides of honey may develop differently on the layer from saccharose.

At least two analyses were made per sample. The final result was expressed as the arithmetic mean of the parallel analyses.

\section{Other analyses}

Crystallization was determined by eye and by testing the consistency in room temperature. A five-part scale, from liquid $(0)$ to hard, well crystallized (4) honey, was used. Dry matter was determined with the refractometer $(\mathrm{ABBE})$. The refractometer indices were transformed to the water content using the table of WEDMORE (1955).

Ascorbic acid (C) was determined colorimetrically with Tillman's reagent; in addition to total ascorbic acid, the corrected ascorbic acid content was determined by formalin correction. Thiamine $\left(\mathrm{B}_{1}\right)$ was determined by the fluorometric tiochrome method and Decalso purification. Riboflavin $\left(\mathrm{B}_{2}\right)$ and niacin were determined microbiologically: $\mathrm{B}_{2}$ with Lactobacillus case $i$ and niacin with $L$. plantarum. The vitamin analyses were made by the Technical Research Centre of Finland.

Acidity was determined by $\mathrm{NaOH}$-titration, diastase activity as described by WHITE et al. (1962) and hydroxymethylfurfural by the method of WINKLER (1955). These analyses were made by the Soil Analysis Service Ltd.

\section{Results}

Of the total sugars, on an average $47-48 \%$ was fructose, $44 \%$ glucose and $8-10 \%$ oligosaccharides. The ratio $\mathrm{F} / \mathrm{G}$ was 1.1 . DM averaged $82.4 \%$ and $\mathrm{pH} 3.9$ (Table 1). The honey had generally already crystallized when examined in the autumn of the current year. 
The means of the five vitamin analyses were: ascorbic acid $2700 \mu \mathrm{g} / 100$ $\mathrm{g}$, thiamine $9 \mu \mathrm{g} / 100 \mathrm{~g}$, riboflavin $39 \mu \mathrm{g} / 100 \mathrm{~g}$ and niacin $1020 \mu \mathrm{g} / 100 \mathrm{~g}$ (Table 2). The results concerning acidity, diastase activity and hydroxymethylfurfural are given in Table 3 .

Table 1. Average sugar composition ( $\%$ of total sugars), dry matter $(\%)$ and $\mathrm{pH}$ in $1977(\mathrm{n}=90)$ and in $1978(n=68)$.

\begin{tabular}{lcccc}
\hline & Mean & $\begin{array}{c}\text { Standard } \\
\text { deviation }\end{array}$ & $\begin{array}{c}\text { Range } \\
1977-1978\end{array}$ \\
\hline Fructose & 1977 & 47.9 & 3.2 & $38.5-58.4$ \\
Glucose & 1978 & 46.6 & 2.9 & $34.3-54.5$ \\
Oligosaccharides & 1977 & 44.2 & 3.4 & $4.5-15.9$ \\
Dry matter & 1978 & 43.6 & 3.1 & $78.0-85.0$ \\
pH & 1977 & 7.9 & 2.5 & 1.9 \\
& 1978 & 9.8 & 1.1 & $3.6-4.6$ \\
\hline
\end{tabular}

Table 2. Vitamin contents $(\mu \mathrm{g} / 100 \mathrm{~g})$ of the five subsamples.

\begin{tabular}{|c|c|c|c|c|c|c|}
\hline \multirow[b]{2}{*}{ Sample } & \multirow[b]{2}{*}{ no. } & \multicolumn{2}{|c|}{ C } & \multirow[t]{2}{*}{$\mathrm{B}_{1}$} & \multirow[t]{2}{*}{$\mathrm{B}_{2}$} & \multirow[t]{2}{*}{ Niacin } \\
\hline & & total & corr. & & & \\
\hline 1977 & 1 & 3100 & 800 & 8 & 40 & 940 \\
\hline \multirow[t]{4}{*}{1978} & 1 & 2600 & 700 & 9 & 44 & 970 \\
\hline & 2 & 2300 & 1000 & 7 & 21 & 880 \\
\hline & 3 & 2200 & 800 & 9 & 49 & 1080 \\
\hline & 4 & 3300 & 100 & 10 & 40 & 1250 \\
\hline
\end{tabular}

Table 3. Acidity (meq/kg), diastase activity (Cothe scale) and hydroxymethylfurfural content ( $\mathrm{HMF}, \mathrm{mg} /$ $\mathrm{kg}$ ) in the subsamples of ten honeys.

\begin{tabular}{cccccc}
\hline \multicolumn{2}{c}{ Sample } & no. & Acidity & $\begin{array}{c}\text { Diastase } \\
\text { activity }\end{array}$ & HMF \\
\hline \multirow{2}{*}{1977} & 1 & 23.3 & 19.8 & 20.1 \\
& 2 & 13.6 & 9.7 & 17.8 \\
& 3 & 28.1 & 46.1 & 9.4 \\
& 4 & 23.7 & 26.7 & 15.4 \\
& 5 & 32.8 & 37.5 & 38.3 \\
& 5 & 17.8 & 21.4 & 24.9 \\
& 1 & 21.8 & 38.4 & 6.7 \\
& 1 & 20.6 & 32.1 & 9.7 \\
\hline
\end{tabular}


In 1977 the average proportion of fructose in the total sugars was 1.6 $\%$ - units higher $\left(\mathrm{t}=3.17^{* \%}, \mathrm{dfv}_{119}\right)$ and the average proportion of oligosaccharides $2.1 \%$-units lower $\left(t=5.25^{\% * \%}, \mathrm{df}={ }_{119}\right)$ than in 1978. The 1977 honeys were more strongly crystallized than the 1978 honeys (Fig. 2, $\mathrm{t}=4.57 \% \%, \mathrm{df}=119$ ).

In 1978 the proportion of glucose was highest in the honeys of southern Finland $\left(\mathrm{F}(3,64)=5.89^{* *}\right)$. Although not statistically significant, the regional trends in the fructose and oligosaccharide contents in 1978 accorded with those observed in 1977 (Figs. 3-5). Also, in both the years the southern samples were most strongly crystallized (Fig. 6, $1977 \mathrm{~F}(3,86)=6.60 \% * \%, 1978$ $\mathrm{F}(3,64)=6.24 \% \%)$.

In 1977, the dry matter content of the honeys removed from the hives before 8 August was on an average $1 \%$ unit higher than the content of the honeys removed on or after 8 August from the same apiaries $(t=2.42 \%$, $\mathrm{df}=29)$; in 1978 no significant difference existed. The date 8 August was chosen on the basis of the two-peaked frequency distribution of the dates of the removal of the honey crop; see VARIS et al. (1982). In 1978, the dry matter content of honeys produced by Italian bees was ca. $1 \%$-unit higher than the content of honeys produced by bees of mixed race or dark bees (Table 4).

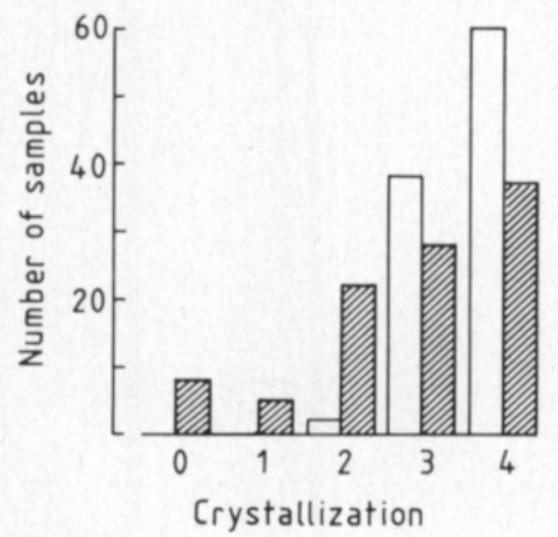

Fig. 2. Distribution of the honey samples by crystallization classes $(0=$ liquid, $4=$ hard $)$ in 1977 and 1978 (shaded).

Table 4. Dry matter content (\%) of the honey of different bee races.

\begin{tabular}{lccccc}
\hline \multicolumn{1}{c}{} & & Italian bees & Dark bees & Mixed race & \\
\hline \multirow{1}{*}{1977} & M & 82.6 & 82.3 & 82.2 & \\
& $\mathrm{D}$ & 1.5 & 0.9 & 1.1 & $\mathrm{~F}(2,83)=0.787 \mathrm{~ns}$ \\
& $\mathrm{n}$ & 41 & 11 & 34 & \\
& $\mathrm{M}$ & 83.0 & 81.9 & 81.9 & \\
& $\mathrm{D}$ & 0.9 & 1.4 & 1.0 & $\mathrm{~F}(2,63)=8.156^{\text {*** }}$ \\
& $\mathrm{n}$ & 32 & 10 & 24 & \\
\hline
\end{tabular}




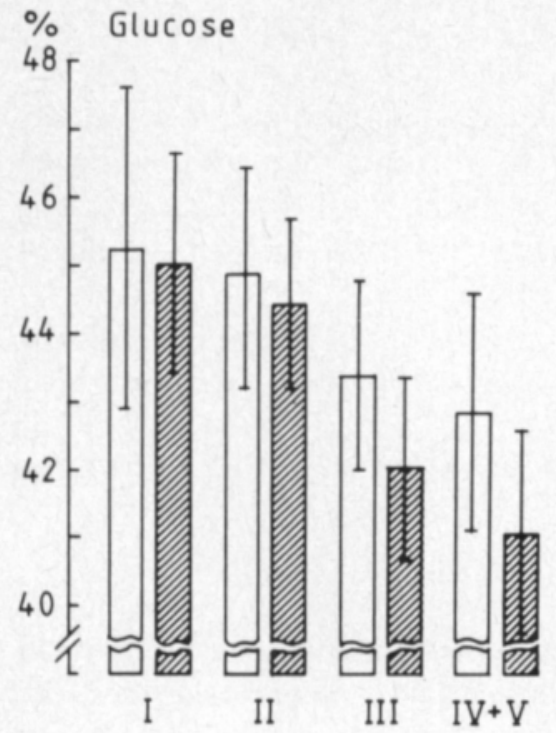

Figs. 3-5. Zonal levels of glucose, oligosaccharides and fructose as mean proportions of total sugars in honeys in 1977 and 1978 (shaded). The vertical lines indicate standard deviations.
Fig. 6. Zonal means of crystallization in 1977 and 1978 (shaded). The vertical lines indicate standard deviations.
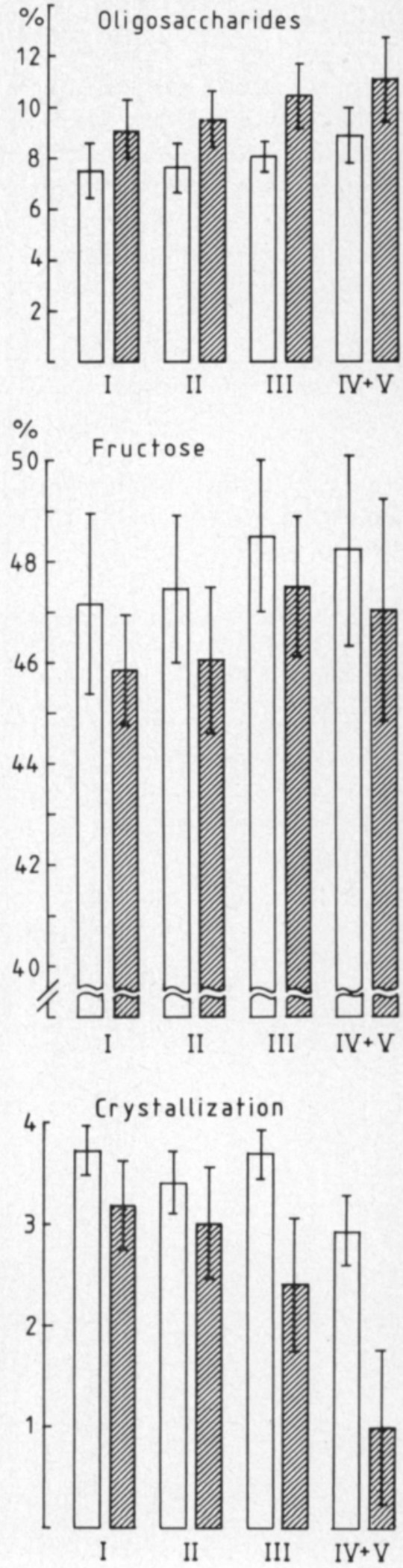


\section{Correlations}

The proportion of glucose was positively correlated with the Brassicaceae pollen count and the total pollen count. In contrast, the proportion of oligosaccharides was (in 1978) negatively correlated with these counts. The proportion of oligosaccharides was positively correlated with the count of Trifolium repens $+T$. hybridum pollen (Table 5).

The proportion of oligosaccharides was more strongly correlated with the proportion of glucose than with the proportion of fructose:

1977

$$
-0.411^{* \% *}
$$$$
-0.146 \mathrm{~ns}
$$

1978

$-0.503^{\text {해 }}$

$-0.305^{*}$

In 1978, the proportion of glucose was highest in the well crystallized honeys (Fig. $7, \mathrm{~F}(4,63)=3.13^{\% *}$ ), and the proportion of oligosaccharides was

Table 5. Statistically significant correlations between proportions of sugars (\% of total sugars) and counts of pollen types ( $t$-test, $\mathrm{H}_{0}: \beta=0$ ).

\begin{tabular}{|c|c|c|c|}
\hline & 1977 & 1978 & Total \\
\hline $\begin{array}{c}\text { Glucose/Brassicaceae pollen } \\
\text { /Total pollen }\end{array}$ & $\begin{array}{l}.271^{\text {fn }} \\
.121 \mathrm{~ns}\end{array}$ & $\begin{array}{l}.388^{\text {n+n }} \\
.313^{\text {nh }}\end{array}$ & $\begin{array}{l}.316^{7 n+4} \\
.205^{*}\end{array}$ \\
\hline 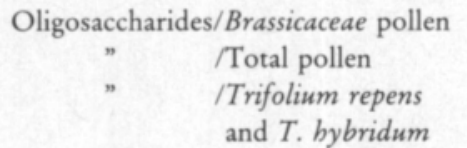 & $\begin{array}{r}-.180 \mathrm{~ns} \\
-.112 \mathrm{~ns} \\
.218^{n}\end{array}$ & $\begin{array}{l}-.449^{* 3 * 4} \\
-.292^{*} \\
.252^{*}\end{array}$ & $\begin{array}{l}-.301^{\text {\#\#㐘 }} \\
-.216^{\text {\#\# }} \\
.091 \mathrm{~ns}\end{array}$ \\
\hline
\end{tabular}
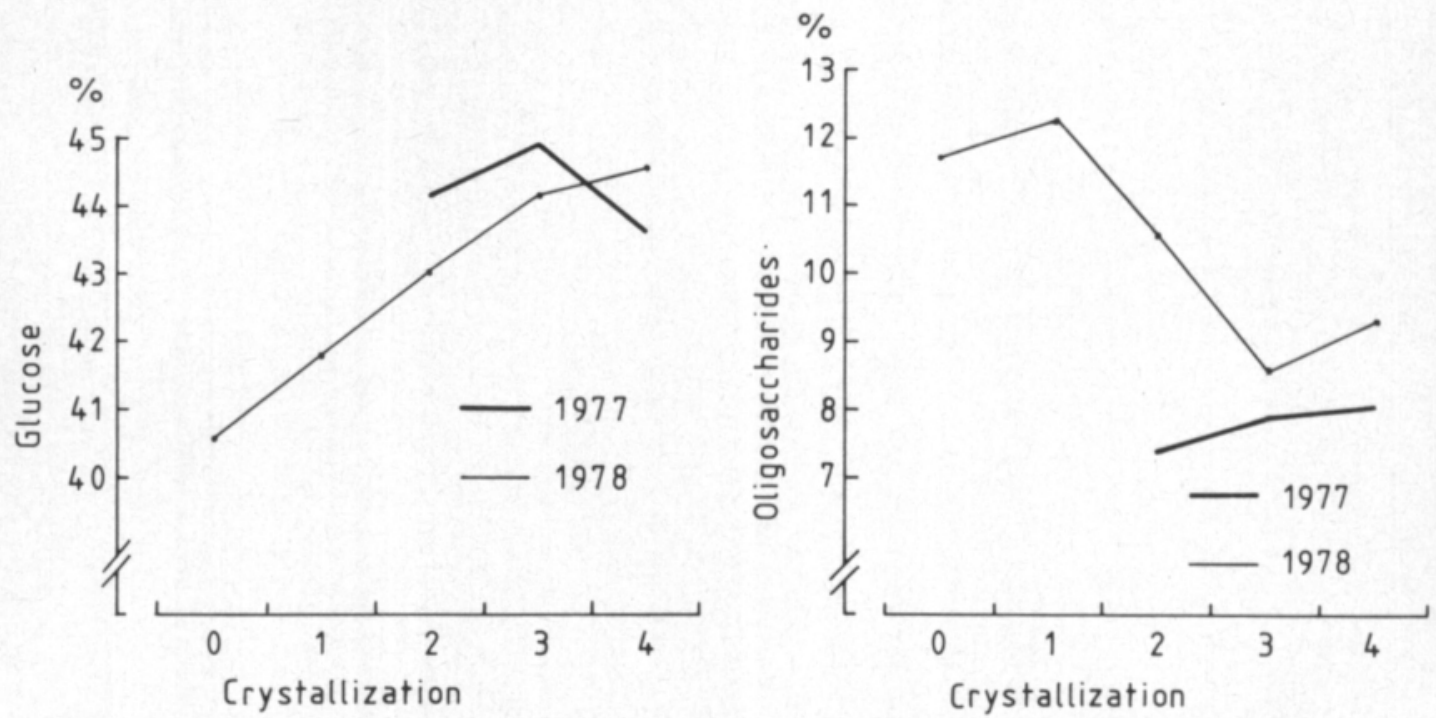

Figs. 7 and 8. Proportions of glucose and oligosaccharides in total sugars in relation to crystallization $(0=$ liquid, $4=$ hard $)$. 
highest in the honeys that had not yet crystallized (Fig. 8, $\left.\mathrm{F}(4,63)=5.02^{* *}\right)$. In 1978 also, both the Brassicaceae pollen count (Fig. 9, F $(4,63)=2.90 \%$ ), and the total pollen count (Fig. 10, F $\left.(4,63)=3.00^{*}\right)$ were higher in the crystallized
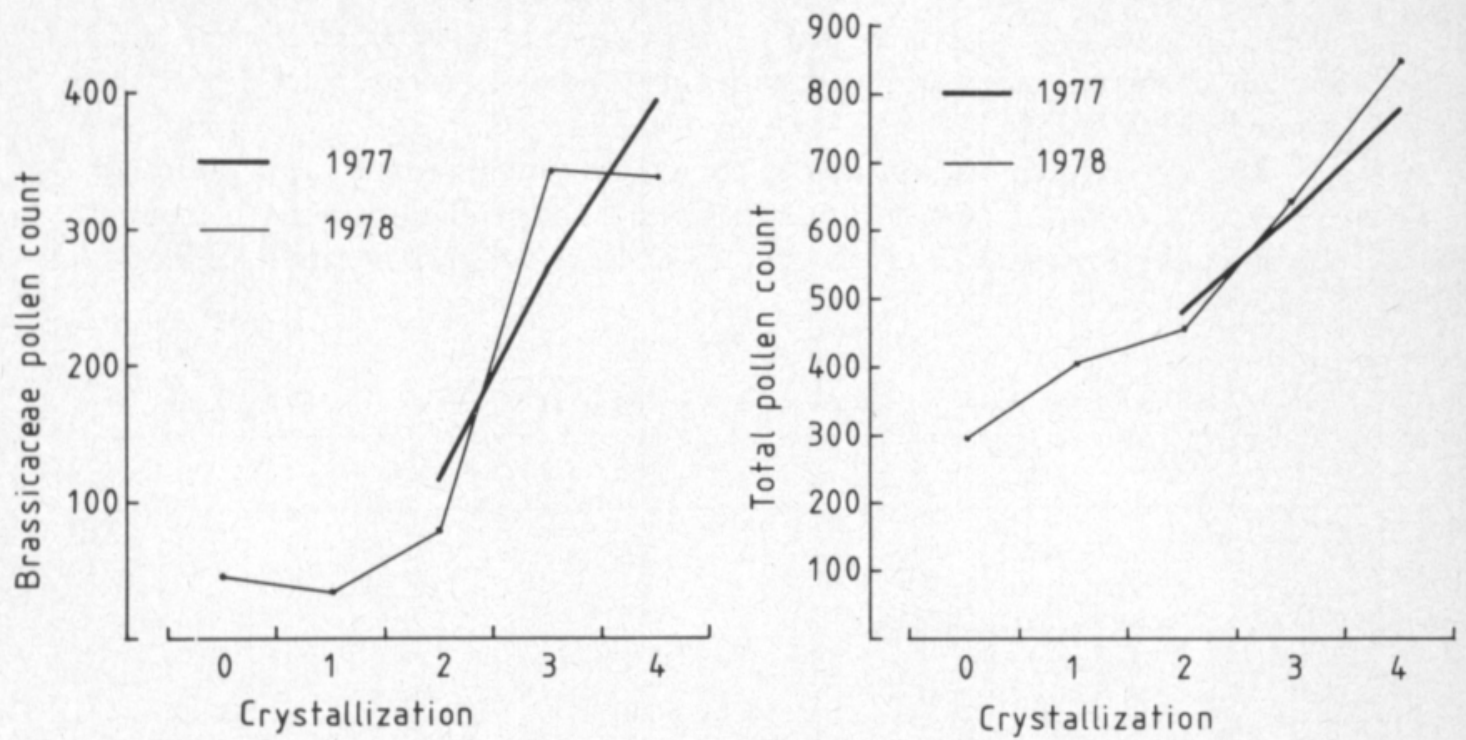

Figs. 9 and 10. Brassicaceae pollen count and total pollen count in relation to crystallization $(0=$ liquid, $4=$ hard).

Table 6. The ratios $\mathrm{G} / \mathrm{O}, \mathrm{F} / \mathrm{G}, \mathrm{G} / \mathrm{W}$ and $(\mathrm{G}-\mathrm{W}) / \mathrm{F}$ in honey classified by crystallization, from liquid $(0)$ to hard (4). $(\mathrm{G}=$ glucose, $\mathrm{O}=$ oligosaccharides, $\mathrm{F}=$ fructose and $\mathrm{W}=$ water.)

\begin{tabular}{|c|c|c|c|c|c|c|c|c|}
\hline & & & 0 & 1 & 2 & 3 & 4 & \\
\hline $\mathrm{n}$ & 1977 & & 0 & 0 & 5 & 37 & 48 & \\
\hline $\mathrm{n}$ & 1978 & & 7 & 5 & 13 & 21 & 22 & \\
\hline \multirow[t]{4}{*}{$\mathrm{G} / \mathrm{O}$} & 1977 & M & - & - & 6.21 & 6.16 & 5.72 & \\
\hline & & $\mathrm{D}$ & - & - & 1.40 & 2.00 & 1.59 & $\mathrm{~F}(2,87)=0.612 \mathrm{~ns}$ \\
\hline & 1978 & M & 3.75 & 3.58 & 4.32 & 5.47 & 5.11 & \\
\hline & & $\mathrm{D}$ & 1.39 & .97 & 1.18 & 1.80 & 1.74 & $\mathrm{~F}(4,63)=2.923^{*}$ \\
\hline \multirow[t]{4}{*}{$\mathrm{F} / \mathrm{G}$} & 1977 & M & - & - & 1.10 & 1.06 & 1.12 & \\
\hline & & $\mathrm{D}$ & - & - & .10 & .16 & .15 & $\mathrm{~F}(2,87)=1.319 \mathrm{~ns}$ \\
\hline & 1978 & M & 1.17 & 1.10 & 1.08 & 1.08 & 1.04 & \\
\hline & & D & .20 & .16 & .11 & .13 & .11 & $\mathrm{~F}(4,63)=1.395 \mathrm{~ns}$ \\
\hline \multirow[t]{4}{*}{$\mathrm{G} / \mathrm{W}$} & 1977 & M & - & - & 2.12 & 2.06 & 2.10 & \\
\hline & & D & - & - & .29 & .30 & .20 & $\mathrm{~F}(2,87)=0.303 \mathrm{~ns}$ \\
\hline & 1978 & M & 1.95 & 2.06 & 2.02 & 2.02 & 2.14 & \\
\hline & & D & .31 & .12 & .16 & .21 & .24 & $F(4,63)=1.576 \mathrm{~ns}$ \\
\hline \multirow{4}{*}{$\begin{array}{c}\text { G-W/ } \\
\text { F }\end{array}$} & 1977 & M & - & - & .48 & .49 & .48 & \\
\hline & & D & - & - & .09 & .13 & .10 & $\mathrm{~F}(2,87)=0.231 \mathrm{~ns}$ \\
\hline & 1978 & M & .42 & .48 & .47 & .47 & .52 & \\
\hline & & D & .14 & .11 & .08 & .09 & .10 & $\mathrm{~F}(4,63)=1.384 \mathrm{~ns}$ \\
\hline
\end{tabular}


than in the liquid honeys. The ratios $F / G, G / W$ or $(\mathrm{G}-\mathrm{W}) / \mathrm{F}$ did not vary statistically in respect of crystallization, but the ratio glucose/oligosaccharides did (Table 6). The ratio G/O correlated with the Brassicaceae pollen count in both the years, weakly in $1977\left(0.211^{*}\right)$, but more strongly in 1978 $(0.571, \mathrm{~F}(1,66)=32.01 \% * \%)$. The indices $\mathrm{F} / \mathrm{G}(-0.234 \%)$ and $(\mathrm{G}-\mathrm{W}) / \mathrm{F}\left(0.235^{*}\right)$ were only weakly correlated with this count and only in 1977 . The total pollen count was not correlated with these indices, except in 1978 with the ratio $\mathrm{G} / \mathrm{O}(0.363 * \%)$.

The dry matter was positively correlated with the counts of pollen of Salix spp., anemones and Sorbus aucuparia. The correlations with the counts of pollen of Brassicaceae (1978 only) and Apiaceae were negative (Table 7).

Table 7. Statistically significant correlations between dry matter (DM) and counts of pollen types.

\begin{tabular}{|c|c|c|}
\hline & 1977 & 1978 \\
\hline $\begin{array}{l}\text { DM/Salix pollen } \\
\text { "/anemone }{ }^{1} \text { pollen } \\
\text { "/Sorbus aucuparia pollen } \\
\text { " /Apiaceae pollen } \\
\text { " / Brassicaceae pollen } \\
\text { ' Anemone, Pulsatilla, Hepatica spp. }\end{array}$ & $\begin{array}{l}.265^{n 4} \\
- \\
.156 \mathrm{~ns} \\
-.320^{* 4} \\
-.013 \mathrm{~ns}\end{array}$ & $\begin{array}{r}.323^{\# \#} \\
.258^{*} \\
.271^{\#} \\
-.245^{*} \\
-.299^{*}\end{array}$ \\
\hline
\end{tabular}

\section{Discussion}

The results obtained for the main chemical properties of Finnish honeys from 1977 and 1978 agree with those of the analyses made by PUROKOSKI and FORSIUS (unpublished) in 1962 and 1963. Also, these results fit well with the data on the average chemical composition of the world honeys, surveyed by WHITE (1975). The mean of 1.1 for the ratio $F / G$ is fairly typical.

The contents of ascorbic acid, thiamine, riboflavin and niacin in the five combined samples agree with the data collected by WHITE (1978). The acidity, diastase activity and hydroxymethylfurfural content of the subsample of ten honeys comply with the requirements of the Finnish honey statute (Statute no. 911/71, given in Helsinki in 1971).

The results concerning dry matter suggest that some causality may exist between dry matter and botanical origin, and also between dry matter and bee race. However, the dry matter content is not a stable property of honey; it also depends on atmospheric humidity and other factors.

\section{Rape honey}

Finnish honey containing Brassicaceae pollen mostly originates from turnip rape (Brassica rapa ssp. oleifera), in minor quantities also from rape $(B$. 
napus v. oleifera) and from wild Brassicaceae species (VARIS et al. 1982). The honey containing Brassicaceae pollen will here be called rape honey.

The correlations of the Brassicaceae pollen count to glucose and oligosaccharides indicate that in rape honey the proportion of glucose is higher and the proportion of oligosaccharides lower than average. This result agrees with those of the earlier studies (PUROKOSKI and FORSIUS, unpublished, MAURIZIO 1959, 1964, POURTALLIER and TALIERCIO 1970, RAVN et al. 1975).

The positive correlation between Brassicaceae pollen and crystallization indicates that the tendency of rape honey to crystallize is stronger than average. This agrees with reports of rapid crystallization of (turnip) rape honey (e.g. CRANE 1975). The 1977 results can neither support nor disprove this conclusion, as only crystallized honeys were found.

As glucose is the crystallizing constituent of honey, the sugar composition can be supposed to regulate the tendency to crystallize. Accordingly, the correlations of glucose and oligosaccharides with crystallization may be assumed to indicate a causal relation. Hence, the heavy crystallization of rape honey is explained by its relatively high glucose content (or glucose/oligosaccharides ratio). MAURIZIO (1959) suggested that the crystallization of rape honey was caused by the low fructose/glucose ratio.

The total pollen count was positively correlated with the Brassicaceae pollen count (VARIS et al. 1982), and hence with the proportion of rape honey. Thus, the correlation of the total pollen count with the composition and properties of honey were identical to the corresponding correlations of the Brassicaceae pollen count and were caused by the characteristics of rape honey. On the other hand, as pollen grains may function as crystallization initiators (WHITE 1978), the high pollen count in rape honey may partly explain its tendency to crystallize.

In addition to rape honey, the data allow only a brief discussion of clover honey: If the presence of clover pollen is indicative of clover honey, its correlation with oligosaccharides suggests a higher than average content of oligosaccharides in clover honey. MAURIZIO (1959) reported that clover nectar contains more saccharose than average. RAVN et al. (1975) suggested that this is directly reflected in the sugar composition of clover honey. However, although the fructose/glucose ratio is low in the nectar of clover, it is relatively high, over one, in clover honey (MAURIZIO 1959).

\section{Crystallization indices}

The ratios $F / G, G / W$ and $(\mathrm{G}-\mathrm{W}) / \mathrm{F}$ did not explain the tendency to crystallize as well as the ratio glucose/oligosaccharides, which supports the proposal of CHANDLER et al. (1974) that more attention should be paid to the oligosaccharide component in studying crystallization. However, as the oligosaccharide component was not further fractioned or analysed, we do not consider the ratio as such as a general index of crystallization. 


\section{Seasonal and regional variation}

The preceding observations on the properties of rape honey make it easy to understand the regional variation in the composition and properties of the honeys. The higher glucose content and stronger crystallization of the honeys of the southern zones I and II are characteristic of rape honey and are caused by the concentration of rape acreage in these zones. Rape honey predominates in this part of Finland (VARIS et al. 1982).

The 1977 honeys were all crystallized when examined, and compared with the 1978 honeys, they had a high fructose and low oligosaccharide content. This agrees with earlier observations that honeys with a strong tendency to crystallize have a higher monosaccharide content than honeys in which this tendency is weak or lacking, and which have a higher oligosaccharide content (WHITE et al. 1962). The explanation of the annual variation may be sought in the botanical origin. It also seems that variation in the composition of honey is caused by weatherinduced changes in the composition of nectar and by changes in the function and amount of enzymes secreted by bees.

Acknowledgements. We are grateful to Mrs Liisa Pollari-Miranto for performing the sugar analysis and to Mrs Silja Mäkelä for technical assistance. We would like to thank Mrs Anna Damström for revising the English text and Mr Jorma Löytynoja for drawing the figures. The work was supported financially by the National Research Council for Agriculture and Forestry.

\section{References}

CHANDLER, B. V., FENWICK, D., ORLOVA, T. \& REYNOLDS, T. 1974. Composition of Australian honeys. CSIRO Aust. Div. Food Res. Techn. Pap. 38. 39 p.

CRANE, E. 1975. The flowers honey comes from. Honey - a comprehensive survey. p. 3-76. 3rd Impress. London.

DONER, E. 1977. The sugars of honey - a review. J. Sci. Food Agric. 28: 443-456.

GREENWAY, A. R., GREENWOOD, S. P., RHENIUS, V. J. \& SIMPSON, J. 1975. Unusual severe granulation of winter stores caused by nectar from ivy, Hedera belix, in Ireland. J. Apic. Res. 14: 63-68.

HADORN, H. \& ZURCHER, K. 1974. Zuckerspektrum und Kristallisationstendenz von Honigen. Mitt. Gebiete Lebensm.unters. und Hyg. 65: 407-420.

MARTIMO, E. 1945. Suomalaisen hunajan ominaisuuksista ja alkuperästä. Maatal.tiet. Aikak. 17: 157169.

MAURIZIO, A. 1959. Papierchromatographische Untersuchungeh an Blütenhoningen und Nectar. Ann. Abeille 4: 291-341.

— 1964. Das Zuckerbild blütenreiner Sortenhonige. Ann. Abeille 7: 289-299.

POURTALLIER, J. \& TALIERCIO, Y.1970. Les caracteristiques physicochimiques des miels en fonction de leur origine florale. 1. Application à un projet de normes pour les grandes variétés de miels. Bull. Apic. Doc. Sci. Techn. Inf. 13: 58-68.

RAVN, V., HAMMER, B. \& BARTELS, H. 1975. En sukkerkemisk og pollenanalytisk undersøgelse af nogle danske honningtyper. Tidsskr. Planteavl 79: 13-36. 
SIDDIQUI, I. R. \& FURGALA, B. 1967. Isolation and characterization of oligosaccharides from honey.

I. J. Apic. Res. 6: 139-145.

— \& FURGALA, B. 1968. II. J. Apic. Res. 7: 51-59.

TABOURET, T. 1979. Rôle de l'activité de l'eau dans la cristallisation du miel. Apidologie 10: 341-358.

VARIS, A-L., HELENIUS, J. \& KOIVULEHTO, K. 1982. Pollen spectrum of Finnish honey. J. Scient. Agric. Soc. Finland 54: 403-420.

WEDMORE, E. B. 1955. The accurate determination of the water content of honeys. I. Introduction and results. Bee World 36: 197-206.

WHITE, J. W. 1975. Composition of honey. Honey - a comprehensive survey. p. 157-206. 3rd Impress. London.

- 1978. Honey. Adv. Food Res. 24: 287-374.

- , RIETHOF, M. L., SUBERS, M. H. \& KUSHNIR, I. 1962. Composition of American honeys. U. S. Dept. Agric. Techn. Bull. 1261. 124 p.

WINKLER, O. 1955. Beitrag zum Nachweis und zur Bestimmung von Oxymethylfurfurol in Honig und Kunsthonig. Z. Lebensm.unters. und Forsch. 102: 161-167.

Ms received August 29, 1983

\section{SELOSTUS}

\section{Suomalaisen hunajan koostumus}

\section{Anna-Liisa Varis, Juha Helenius ja Kari Koivulehto}

\section{Helsingin yliopiston maatalous- ja metsäeläintieteen laitos, 00710 Helsinki 71}

Artikkeli on toinen osaraportti laajemmasta hunajan koostumusta selvittelevästä tutkimuksesta. Osatutkimuksen tavoite oli antaa kuva suomalaisen hunajan koostumuksesta pääkomponenttien osalta. Tärkeimpiin vaihtelua aiheuttaviin tekijöihin kiinnitettiin huomiota. Kemiallisten ominaisuuksien ja sïtepölykoostumuksen yhteyksiä tarkasteltiin siitepölyanalyysien tulosten pohjalta.

Vuosina 1977 ja 1978 koottiin 158 hunajanäytettä 70 mehiläishoitajalta 80 mehiläistarhasta. Aineisto edusti suomalaista hunajaa sekä alueellisesti että mehiläisrotujen osalta. Ohutlevykromatografialla määritetty sokerikoostumus oli keskimäärin: $47-48 \%$ fruktoosia, $44 \%$ glukoosia ja noin 8-10\% oligosakkarideja kaikesta hunajan sokerista. Fruktoosi/glukoosi oli 1.1. Kuiva-ainepitoisuus oli keskimäärin $82.4 \%$ ja pH 3.9. Valtion teknisessä tutkimuskeskuksessa viidestä kokoomanäytteestä määritetyt vitamiinipitoisuudet olivat keskimäärin: $2700 \mu \mathrm{g} / 100 \mathrm{~g}$ askorbiinihappoa, $9 \mu \mathrm{g} / 100 \mathrm{~g}$ tiamiinia, $39 \mu \mathrm{g} / 100 \mathrm{~g}$ riboflaviinia ja $1020 \mu \mathrm{g} /$ $100 \mathrm{~g}$ niasiinia. Kiteytyneisyys määritettiin aistinvaraisesti; vuoden 1977 hunajat olivat satokauden jälkeen arvosteltuna kiteytyneempiä kuin vuoden 1978 hunajat vastaavana ajankohtana.

Koostumukseltaan suomalainen hunaja vastaa ulkomaisia hunajia. Sen tasalaatuisuuteen viittaa 1960-luvun alun (FORSIUKSEN ja PUROKOSKEN) ja 1970-luvun lopun (tämän tutkimuksen) analyysitulosten samankaltaisuus. Viiden analysoidun kokoomanäytteen C-, $B_{1}$ - ja niasiini-vitamiinipitoisuudet olivat verraten korkeita. Glukoosin osuus oli positiivisesti ja oligosakkaridien osuus negatiivisesti korreloitunut ristikukkaiskasvien siitepölyn määrään hunajassa. Suhde glukoosi/oligosakkaridit selitti kiteytymistaipumusta paremmin kuin suhteet fruktoosi/glukoosi, glukoosi/vesi tai (glukoosi - vesi)/fruktoosi. 